\title{
REVERSE BREECH EXTRACTION AT CESAREAN SECTION IN SECOND STAGE OF LABOR
}

DOI: 10.36740/WLek202005135

\author{
Leonid B. Markin, Olena S. Rachkevych, Olena M. Zhemela \\ DANYLO HALYTSKY LVIV NATIONAL MEDICAL UNIVERSITY, LVIV, UKRAINE
}

\begin{abstract}
The aim: Taking into consideration the increase in the frequency of urgent C-sections in the second stage of labor and significant technical difficulties in the extraction of deeply impacted fetal head during this operation, the aim of our work was to analyze the current published biomedical data to identify the optimal technical strategies for conducting this type of surgical interventions.

Materials and methods: The search and analysis of current clinical data available in PubMed was performed. We analyzed 9 retrospective and randomized prospective studies with collected data from a total of 974 women (2002-2019).

Conclusions: Analysis of nine prospective and retrospective studies, comparing reverse breech extraction with abdominovaginal technique, revealed a significant advantage and safety of reverse breech extraction. This procedure has been associated with the decrease of traumatic uncontrolled extension of uterine incisions in 2.3-10 times, the time of surgical intervention decreased by 6.5-33 minutes, and intraoperative blood loss was less by 149.5-444 ml as compared with abdominovaginal delivery. Moreover, less intra- and postoperative complications were observed. In conclusion, reverse breech extraction during cesarean section with impacted fetal head is a safe delivery technique that helps to significantly decrease the incidence of maternal complications.
\end{abstract}

KEY WORDS: cesarean section, labor stage second, reverse breech extraction

Wiad Lek. 2020;73(5):1028-1031

\section{INTRODUCTION}

Cesarean section surgery is known for several ages. It described in the Myths of Ancient Greece. According to the legend, Asclepius, a god of Medicine, was extracted by Apollo from the womb of his dead mother [1,2]. Through the centenaries cesarean section (C-section) was an operation of despair to save a child, and almost always meant the death sentence for the mother because the uterine wound was never sutured. In 1876 E. Porro introduced amputations of uterus after $\mathrm{C}$-section. That helped to decrease postoperative mortality almost twice [3]. In 1881, F. Kerer performed C-section using low-segment transverse incision and emphasized the necessity of suturing the muscle layer of uterus (similarly to current surgical methodology) $[1,2,4]$.

The discovery of antibiotics and improvement of surgical techniques made the surgery of $\mathrm{C}$-section an integral part of modern obstetrics, and its frequency is constantly rising both in Ukraine and in the world [5]. However, even in the present time such operation might be accompanied by serious complications for mother and the child. Particularly, technically difficult is C-section surgery in second stage of labor with deeply impacted fetal head. The frequency of such surgeries is approximately $1.5 \%$ of all C-sections and approximately $25 \%$ of urgent $\mathrm{C}$-sections [6,7]. The traditional approach to delivery out fetal head deeply inserted into pelvis and tightly attached to pelvic wall with over-stretched lower segment can lead to significant complications [8,9]. Of note, carrying out the $\mathrm{C}$-section at full cervical dilatation requires a higher transversal hysterotomy, which usually takes place at the level of the fetal shoulders. These factors further complicate the traditional delivery of the presenting head [10].

\section{THE AIM}

Taking into consideration the increase in the frequency of urgent C-sections in the second stage of labor and significant technical difficulties in the extraction of deeply impacted fetal head during this operation, the aim of our work was to analyze the current published biomedical data to identify the optimal technical strategies for conducting this type of surgical interventions.

\section{MATERIALS AND METHODS}

We performed the search and analysis of current clinical data available in PubMed. We analyzed 9 retrospective and randomized prospective studies with collected data from a total of 974 women (2002-2019).

\section{REVIEW AND DISCUSSION}

The most frequent complication of C-section in second stage of labor with difficult delivery of anterior fetal head 
Table I. Analysis of published data to compare reverse breech extraction method (RBE) with abdominovaginal method (AV).

\begin{tabular}{|c|c|c|c|c|c|c|c|c|c|c|c|c|}
\hline \multirow[t]{2}{*}{ 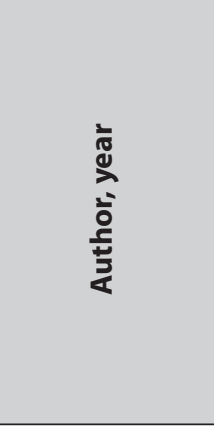 } & \multirow[t]{2}{*}{ 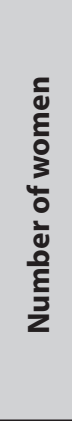 } & \multirow[t]{2}{*}{ 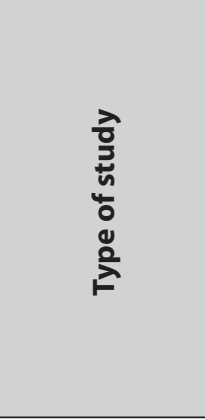 } & \multicolumn{2}{|c|}{ 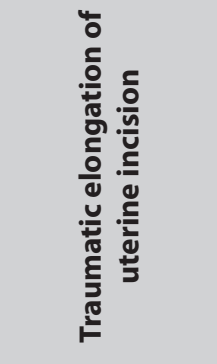 } & \multicolumn{2}{|c|}{ 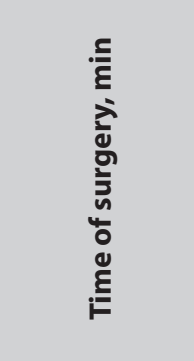 } & \multicolumn{2}{|c|}{ 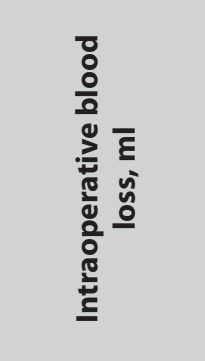 } & \multicolumn{2}{|c|}{ 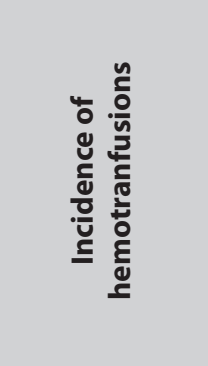 } & \multicolumn{2}{|c|}{ 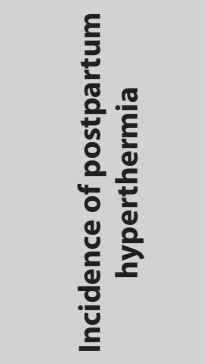 } \\
\hline & & & RBE & AV & RBE & AV & RBE & AV & RBE & AV & RBE & AV \\
\hline $\begin{array}{c}\text { Fasubaa O et al } \\
2002[18]\end{array}$ & 108 & $\begin{array}{l}\text { Prospective } \\
\text { randomized }\end{array}$ & $14.8 \%$ & $46.3 \%$ & 56 & 89 & 899 & 1257 & & & & \\
\hline $\begin{array}{c}\text { Levy R et al } \\
2005 \text { [10] }\end{array}$ & 48 & Retrospective & $15 \%$ & $50 \%$ & & & & & & & $5 \%$ & $46 \%$ \\
\hline $\begin{array}{c}\text { Chopra S et al } \\
2009[22]\end{array}$ & 182 & Retrospective & $2.2 \%$ & $22.8 \%$ & & & & & & & & \\
\hline $\begin{array}{c}\text { Frass K et al } \\
2011[19]\end{array}$ & 118 & $\begin{array}{l}\text { Prospective } \\
\text { randomized }\end{array}$ & $5 \%$ & $40,6 \%$ & 52.9 & 67.2 & 787 & 1231 & & & & \\
\hline $\begin{array}{c}\text { Bastani P et al. } \\
2012[24]\end{array}$ & 59 & Retrospective & $17.2 \%$ & $50 \%$ & & & & & $3.4 \%$ & $10 \%$ & $10.3 \%$ & $53.3 \%$ \\
\hline $\begin{array}{c}\text { Kadhum TJ } \\
2009 \text { [23] }\end{array}$ & 50 & Prospective & $24 \%$ & $56 \%$ & & & & & $16 \%$ & $40 \%$ & & \\
\hline $\begin{array}{c}\text { Saleh S et al. } \\
2014 \text { [20] }\end{array}$ & 80 & $\begin{array}{l}\text { Prospective } \\
\text { randomized }\end{array}$ & $20 \%$ & $50 \%$ & 59.7 & 75.2 & 878 & 1321 & $5 \%$ & $25 \%$ & & \\
\hline $\begin{array}{l}\text { Nooh A et al } \\
2017 \text { [21] }\end{array}$ & 192 & $\begin{array}{l}\text { Prospective } \\
\text { randomized }\end{array}$ & $18,8 \%$ & $47,9 \%$ & & & & & $2.1 \%$ & $11.5 \%$ & $3.1 \%$ & $19.8 \%$ \\
\hline $\begin{array}{l}\text { Lenz F et al } \\
2019[25]\end{array}$ & 137 & Retrospective & $9.1 \%$ & $35.4 \%$ & 38.3 & 44.8 & 562.7 & 712.2 & & & & \\
\hline
\end{tabular}

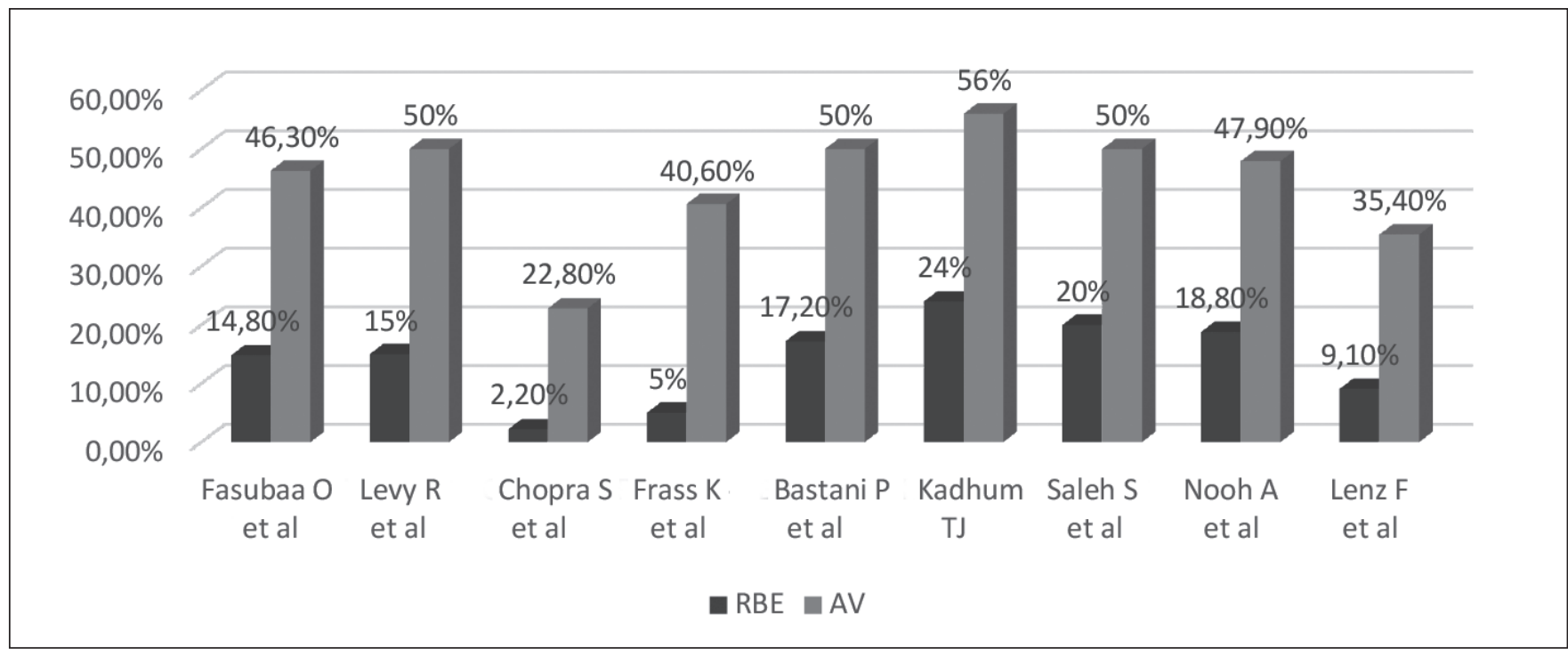

Figure 1. Analysis of published data demonstrating the incidence of unintended extension of uterine incision following application of reverse breech extraction (RBE) vs. abdominovaginal (AV) method. [10,18,19,20,21,22,23,24,25].

is traumatic uncontrolled extension of uterine incision leading to increase of intraoperative blood loss, time of surgical intervention, potential blood transfusion, and likelihood of infection [11]. Furthermore, difficulties during child delivery might cause damage of urinary bladder and neonatal birth injuries. [6,7,9,12,13]. Several approaches have been proposed to solve such problems:

1. Method of intraoperative tocolysis. Ritodrine, terbutaline, nitroglycerine and other tocolytics have been used to facilitate child delivery during C-section. However, 
in the current literature of evidence-based medicine, we were not able to find the data supporting the positive effect of intraoperative tocolysis on maternal and perinatal outcomes during $\mathrm{C}$-section in second stage of labor with deeply impacted fetal head $[13,14,15]$.

2. Vacuum extraction or forceps head delivery appeared to be poorly efficient because application of forceps in the prolonged second stage of labor and deeply impacted fetal head could be also traumatic for the lower segment of the uterus [12]

3. Patwardhan Manoeuvre. This method was proposed by Indian doctor Patwardhan in 1957. With the head deeply impacted in the pelvis, incision is usually made in the lower uterine segment on the level of the anterior shoulder, which is delivered out first. Next, with gentle traction on this shoulder, the posterior shoulder, body and head of the child are subsequently delivered out [16]. Patwardhan method can prevent traumatic injury of the lower uterine segment with deeply impacted foetal head, but technically it is not a simple procedure. Few published data demonstrate safety of this technique for mother and child $[13,17]$.

4. Abdominovaginal method (AV) (push-method). With this method, the assistant is pushing the head of the fetus up by four fingers from the vagina and the surgeon is delivering it by regular procedure through the uterine incision. Most of the Authors emphasize that from the point of view on potential fetal head injury, pushing it with four fingers is safer than with one or two. $[7,12,13]$. This technique is currently most common because of its technical simplicity and efficiency.

5. Reverse breech extraction (RBE) (pull method) involves the delivery of the fetus in cephalic presentation by pelvic end. After making a uterine incision, the surgeon inserts his/her hand into uterus to the direction of fundus, reaches for the fetal foot, and through the wound consequently delivers legs, body and, lastly, the head $[7,12,13]$. Although this technique is widely used in different countries of the World, it is less known in Ukraine, and unfortunately almost not mentioned in Ukrainian studies and clinical protocols. All randomized clinical investigations performed in different countries demonstrated significant advantages and safety of reverse breech extraction technique (pull method) as compared with abdominovaginal (push method) $[18,19,20,21]$ (Table I).

Since the main complication of $\mathrm{C}$-section in second stage of labor with the delivery of deeply impacted fetal head is an uncontrolled traumatic extension of uterine incision, which entails a majority of further complications, such as the increase in intraoperative blood loss, time of operation, increase in the frequency of needs in hemotransfusion, etc., in Figure 1 we demonstrated a significant reduction of this problem by using reverse breech extraction in comparison to abdominovaginal method.

According to the available data from the studies performed in different countries (Table I), pull method was associated with the decrease of traumatic elongation of uterine incision in 2.3-10.4 times less than using push method. Time of surgical intervention was decreased to 6.5-33 min, intraoperative blood loss was decreased on 149.5-444 ml, need in blood transfusion and rate of postsurgical infections were also reduced accordingly. Concerning fetal state, we found only one study analyzing the neonatal complications [23], which reveals that reverse breech extraction was associated with less frequent cases of Apgar score under 7, (specifically 8.3\% vs. 21.9\%) as compared with abdominovaginal method [12]. The meta-analysis, performed by Berhan $Y$ et al [26] find that abdominovaginal method was associated with more perinatal deaths and admissions to the neonatal intensive care unit comparing to reverse breech extraction. Other published studies did not reveal any significant differences in the health of a newborn in relation to the methods of extraction.

\section{CONCLUSIONS}

Current evidence-based medical researches reveals that reverse breech extraction during cesarean section with deeply impacted fetal head is a safe delivery technique that helps to significantly decrease the incidence of maternal complications.

\section{REFERENCES}

1. Young J.H. Caesarean section. The history and development of the operation from earliest times. London: H.K.Lewis. 1944.

2. Trolle D. The history of caesarean section. Copenhagen:C.A.Rietzel. 1982.

3. Porro E. Della amputazione utero-ovarica come complement di talio cesareo. Ann Univ Med Chir (Milan). 1876; 237:289-350.

4. Kehrer F.A. Ueber ein modificintes verfahren biem kaiserschnitte. Arch Gynakol. 1882; 19:177-209

5. Baskett T.F., Calder A.A., Arulkumarai S. Munro Kerr's Operative Obstetrics. 12th edition. Elsevier Ltd; 2007.

6. Chopra S. Disengagement of the deeply engaged fetal head during cesarean section conventional method versus reverse breech extraction - review of literature. Clinics Mother Child Health. 2016; 13:239. doi:10.4172/2090-7214.1000239

7. Manning J.B., Tolcher M.C., Chandraharan E. et al. Delivery of an impacted fetal head during cesarean: a literature review and proposed management algorithm. Obstet Gynecol Surv. 2015;70(11):719-24.

8. Asicioglu 0., Gundorduk K., Yildirim G. et al. Second-stage vs first stage caesarean delivery: comparison of maternal and perinatal outcomes. J Obstet Gynaecol. 2014; 34:598-604.

9. Giugale L.E., Sakamoto S., Yabes J. et al. Unintended hysterotomy extension during caesarean delivery: risk factors and maternal morbidity. J Obstet Gynaecol. 2018; 38(8):1048-1053. doi: 10.1080/01443615.2018.1446421.

10. Levy R., Chernomoretz T., Appelman Z. et al. Head pushing versus reverse breech extraction in cases of impacted fetal head during Cesarean section. Eur J Obstet Gynecol Reprod Biol. 2005;121(1):24-6.

11. Lurie S., Raz N., Boaz M. et al. Comparison of maternal outcomes from primary cesarean section during the second compared with first stage of labor by indication for the operation. Eur J Obstet Gynecol Reprod Biol. 2014;182:43-7. doi:10.1016/j.ejogrb.2014.08.025

12. Barbiieri R.L. Difficult fetal extraction at caesarean delivery:What should you do? OBG Management. 2012;24(1):8-12. 
13. Jeve Y.B., Navti O.B., Konje J.C. Comparison of techniques used to deliver a deeply impacted fetal head at full dilatation: a systematic review and meta-analysis. BJOG. 2016; 123:337-45.

14. Waterfall H., Grivell R.M., Dodd J.M. Techniques for assisting difficult delivery at caesarean section. Cochrane Database Syst Rev. 2016; 1:CD004944. doi: 10.1002/14651858

15. Dodd J.M., Reid K. Tocolysis for assisting delivery at caesarean section. Cochrane Database Syst Rev. 2006; (4):CD004944

16. Patwardhan B.D., Motashaw N.D. Caesarean Section. J Obstet Gynecol India. 1957; 8:1-15.

17. Saha P.K., Gulati R., Goel P. et al. Second stage caesarean section: evaluation of patwardhan technique. J Clin Diagn Res. 2014;8(1):93-5. doi:10.7860/JCDR/2014/6709.3782

18. Fasubaa 0.B., Ezechi 0.C., Orji E.O. et al. Delivery of the impacted head of the fetus at cesarean section after prolonged obstructed labour: a randomised comparative study of two methods. J Obstet Gynaecol. 2002; 22(4): 375-8.

19. Frass K.A., Al Eryani A., Al-Harazi A.H. Reverse breech extraction versus head pushing in cesarean section for obstructed labor. A comparative study in Yemen. Saudi Med J. 2011;32(12):1261-6.

20. Saleh H.S., Kassem G.A., Mohamed M.S. et al. Pull breech out versus push impacted head up in emergency caesarean section: a comparative study. Open J Obstet Gynec. 2014;4:260-5.

21. Nooh A.M., Abdeldayem H.M., Ben-Affan 0. Reverse breech extraction versus the standard approach of pushing the impacted fetal head up through the vagina in caesarean section for obstructed labor: A randomised controlled trial. J Obstet Gynaecol. 2017;37(4):459-63.

22. Chopra S., Bagga R., Keepanasseril A. et al. Disengagement of the deeply engaged fetal head during cesarean section in advanced labor: conventional method versus reverse breech extraction. Acta Obstet Gynecol Scand. 2009;88(10):1163-6.

23. Kadhum T.J. Head pushing versus reverse breech extraction for delivery of impacted fetal head during Cesarean section. Kufa Med J. 2009:12:200-205.
24. Bastani P., Pouraboldhasem S., Abbasalizadeh F. et al. Comparison of neonatal and maternal outcomes associated with head-pushing and head-pulling methods for impacted fetal head extraction during caesarean delivery. Int J Gynaecol Obstet. 2012; 118:1-3.

25. Lenz F., Kimmich N., Zimmermann R. et al. Maternal and neonatal outcome of reverse breech extraction of an impacted fetal head during caesarean section in advanced stage of labour: a retrospective cohort study. BMC Pregnancy Childbirth. 2019; 19(1): 98. doi: 10.1186/s12884019-2253-3

26. Berhan Y., Berhan A. A meta-analysis of reverse breech extraction to deliver a deeply impacted head during caesarean delivery. Int J Gynecol Obstet. 2014;124(2):99-105.

This work is a part of the research project "Improvement of the obsteric care's monitoring at idiopathic pregnancy loss". State registration number $0117 \mathrm{U} 001080$

\section{ORCID and contributionship:}

Leonid B. Markin - 0000-0002-7775-4543 A,B,D,E

Olena S. Rachkevych - 0000-0002-7107-3886 ${ }^{A, B, D}$

Olena M. Zhemela - 0000-0001-8690-7188 ${ }^{A, B, D}$

\section{Conflict of interest:}

The Authors declare no conflict of interest

\section{CORRESPONDING AUTHOR Olena S. Rachkevych \\ Danylo Halytsky Lviv National \\ Medical University, Lviv, Ukraine \\ tel: +380679233308 \\ e-mail:olena777ra@gmail.com}

Received: 25.01 .2020

Accepted: 31.03 .2020

A - Work concept and design, B - Data collection and analysis, C - Responsibility for statistical analysis,

D - Writing the article, $\mathbf{E}$ - Critical review, F - Final approval of the article 